\title{
Observational Advances in Estimates of Oceanic Heating
}

\author{
Damien Desbruyères $^{1}$ - Elaine L. McDonagh ${ }^{1}$ • Brian A. King1
}

Published online: 26 May 2016

(C) Springer International Publishing AG 2016

\begin{abstract}
Since the early twenty-first century, improvements in understanding climate variability resulted from the growth of the ocean observing system. The potential for a closure of the Earth's energy budget has emerged with the unprecedented coverage of Argo profiling floats, which now provide a decade (2006-2015) of invaluable information on ocean heat content changes above $2000 \mathrm{~m}$. The expertise gained from Argo and repeat hydrography sections motivated the extension of the array toward the ocean bottom, which will progressively reveal the poorly known deep ocean and reduce the uncertainty of its presumed 10-15\% contribution to the 2006-2015 global ocean warming trend of $0.65-0.80 \mathrm{~W} \mathrm{~m}^{-2}$. The sustainability and synergy of various observing systems helped to corroborate numerical models and decipher the internal variability of distinct ocean basins. Due to unique observations of the circulation in the North Atlantic, particular attention is paid to heat content changes and their relationship to dynamic variability in that region.
\end{abstract}

Keywords Oceanic heating - Argo - Repeat hydrography · GO-SHIP · North Atlantic

\section{Introduction}

Observational data show an unequivocal warming of the Earth's climate system since the mid-twentieth century [57].

This article is part of the Topical Collection on Global Energy Budgets

\footnotetext{
Damien Desbruyères

dades@noc.ac.uk

1 National Oceanography Centre, Waterfront Campus, European Way, Southampton SO14 3ZH, UK
}

Every past decade has been warmer than its predecessor, and the year 2015 now stands as the warmest ever recorded [67]. This positive temperature trend at the Earth's surface is driven by a radiative imbalance at the top of the atmosphere (e.g. [2]), which is widely attributed to human activities and the increased concentration of greenhouse gases in the troposphere (e.g. [70]). The global surface signal is, however, being constantly modulated by natural fluctuations of the climate system acting over a wide range of spatial and temporal scales (e.g. volcanic eruptions, solar cycles, oceanic circulation). For instance, those natural changes can significantly reduce the increase in global mean surface temperature over periods of decades (e.g. [45]), and mislead the wider community regarding the fate of global warming [68].

The observational record, however, is becoming complete enough to ascertain the on going rise of the Earth's energy content. Amongst the heat reservoirs, the global ocean plays a critical role in capturing heat from the atmosphere and slowly redistributing it around the globe. More than $90 \%$ of the anthropogenic heat entered the ocean during 2006-2015 at a rate of $0.65-0.80 \mathrm{~W} \mathrm{~m}^{-2}$ [57, 72]. For a few decades, global and regional ocean variability have been increasingly revealed by the synergy of several observing systems maintained and coordinated by strong international collaborations. The repeat of full-depth hydrography sections [66], the remote detection of sea-level changes [10], the systematic sampling of the upper ocean by profiling floats [59] and the maintenance of trans-basin moored arrays [43] became the heart of our current understanding of the ocean's role in climate change. They have, for instance, validated numerical models that provided complete explanations of the recent surface warming slowdown at global scale (e.g. [19, 74]), and also explained regional patterns of heat content changes (e.g. [7]). Important observational 
gaps, however, remain, with the Achilles' heel of climate studies residing in the under-sampled deep ocean and its uncertain contribution of $10-15 \%$ to recent changes in the global heat and sea-level balances [51]. The systematic observation of the deep and abyssal layers at sufficient resolution is needed to average out vertical rearrangements of the heat field and hence capture the anthropogenic warming more effectively. The emergence of a Deep Argo array [30] represents a significant step forward in that direction.

Abraham et al. [1] provided a comprehensive review of the observing systems used to assess temperature and oceanic heat content (OHC) changes in the ocean, and detailed the major $\mathrm{OHC}$ indices and their uncertainties from five decades of in situ measurements (1960-2011). Here, we (1) review recent findings on the twenty-first century OHC variability revealed by the growing observational record, (2) report innovative approaches for elucidating regional mechanisms of $\mathrm{OHC}$ variability from in situ measurements (North Atlantic focus) and (3) inform on the upcoming opportunities for closing the global energy budget.

\section{The Unabated Heating of the Upper Ocean}

\section{The Global Picture Drawn by the Argo Array}

The first deployments for the Argo array of autonomous profiling floats were made in 2000 . The array reached its target fleet size in 2007 with 3000 floats sampling the top $2 \mathrm{~km}$ of the water column on a nominal 10-day cycle [59]. Today, in 2016, the Argo database provides more than a million profiles of temperature (and salinity) with nominal accuracy of $0.002{ }^{\circ} \mathrm{C}$ for temperature and $2.4 \mathrm{dbar}$ for pressure [1]. More than $80 \%$ of the profiles in the current (to 2016) Argo database were obtained after 2006, and the earlier description of the 0-2000 m OHC was consequently found to depend strongly on the choice of climatological references in data-sparse regions [9, 20, 39]. Undersampled areas, particularly located in the southern Hemisphere, may have significantly biased low the estimates of global OHC trends between 1970 and 2004 [16]. The uncertain nature of the multi-decadal record was further highlighted by the difficulty of correcting significant biases in expendable bathythermograph measurements, which represented the main source of upper-ocean temperature profiles before the launch of Argo [23, 40]. Overall, the OHC curves prior to the mid 2000s have large error-bars, and the year-to-year variations typically show limited agreement with the net TOA fluxes estimated from satellite products $[38,64]$. It is therefore for about a decade (since the Argo fleet neared completion) that the observing system has been adequate for the global analysis of upper $\mathrm{OHC}$ changes, although a persistent spread between the various $0-2000 \mathrm{~m} \mathrm{OHC}$ estimates still hampers a robust closure of the current Earth energy budget [71].

Through comparison of three Argo analyses, the global OHC trend above $2000 \mathrm{~m}$ during the period 2006-2015 was estimated as $0.50-0.65 \mathrm{~W} \mathrm{~m}^{-2}$ over the effectively sampled ocean (Fig. 1-from [72]). As expected, the global warming rate shows its strongest magnitude in the first few hundred meters of the water column and the interannual variability above $500 \mathrm{~m}$ shows pronounced changes that control the global temperature variations at the air-sea interface [60]. Those upper OHC changes reflects in large part the ElNiño/Southern Oscillation (ENSO) and its influence on the horizontal tilt of the equatorial thermocline in the Pacific. In addition to this interannual signal, the shift from a positive to a negative phase of the Pacific Decadal Oscillation in the early 2000s significantly cooled the Eastern Pacific, which reduced the positive trend in global mean surface temperature while increasing subsurface heat uptake (e.g. [17, 28, 45]). It is now widely accepted that the global mean surface temperature is a poor indicator of the global heat gain (e.g. [50]).

The most recent OHC trend (2006-2015) was marked by a clear hemispheric asymmetry, with the southern hemisphere heating much faster than northern latitudes [60]. A full understanding for such a striking warming of the Southern Hemisphere extra-tropics across the three oceans is, however, still missing. The inhomogeneous radiative forcing by ozone and aerosols may have played a role [61], so did internal ocean variability. In fact, the horizontal distribution of the OHC trend in the upper layer emphasizes substantial redistribution of heat driven by the intrinsic dynamics of each ocean basin. Amongst them, a strong $\mathrm{OHC}$ rise in the Indian Ocean stood out, with a temperature trend between 2006 and 2015 accounting for $50-70 \%$ of the global OHC trend above $700 \mathrm{~m}$ [49]. Such a rise in the Indian Ocean's OHC presumably originated in the western Pacific following a dynamical response to a shift toward a negative phase of the Interdecadal Pacific Oscillation, and a subsequent intensification of the heat transport through the Indonesian Archipelago [35].

Moving down through the water column, the contribution of the intermediate layer $(700-2000 \mathrm{~m})$ to the global OHC change above $2000 \mathrm{~m}$ was about $50 \%$ of the full water column during 2006-2015 (Fig. 2), that is $20 \%$ higher than the long-term (1955-2010) estimation of [36]. This recent and ongoing increase in the sequestration of heat below the upper layer has been supported by model-based analysis [22] and linked to a combination of multiple underlying mechanisms driven by the local modes of atmospheric variability [69]. In particular, the significant warming of the North Atlantic and Southern Ocean in the depth range of Labrador Sea Water and Antarctic Intermediate Water [8] reinforced the idea of a strong link between convective 
Fig. 1 Ocean warming rates and distributions. a Globally averaged surface temperature anomaly $\left(\mathrm{STA},{ }^{\circ} \mathrm{C}\right)$, from $5 \mathrm{~m}$ Argo OI temperature (red), NOAA (National Oceanic and Atmospheric Administration) global ocean (turquoise) and a 6-month running mean of NOAA global land averages (grey). b Global average ocean temperature anomalies from the Argo OI (contour interval is 0.01 for colours, $0.05^{\circ} \mathrm{C}$ in grey). c Global ocean 0-2000 m heat content anomaly as a function of time, with the OI version a 4-month running mean. d Global average 2006-November 2015 potential temperature trend $\left({ }^{\circ} \mathrm{C}\right.$ per decade). e Zonally integrated heat content trends in $1^{\circ}$ latitude bands from the three mapping methods. For line plots $\mathbf{c}, \mathbf{d}$ and e, the sources are OI (red), RSOI (blue) and RPF (black-dashed). From Wijfells et al. (2016), Nature Climate Change

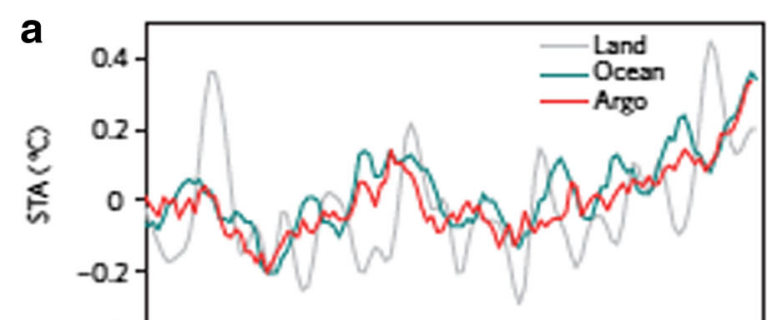

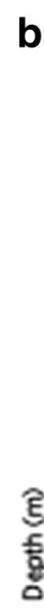

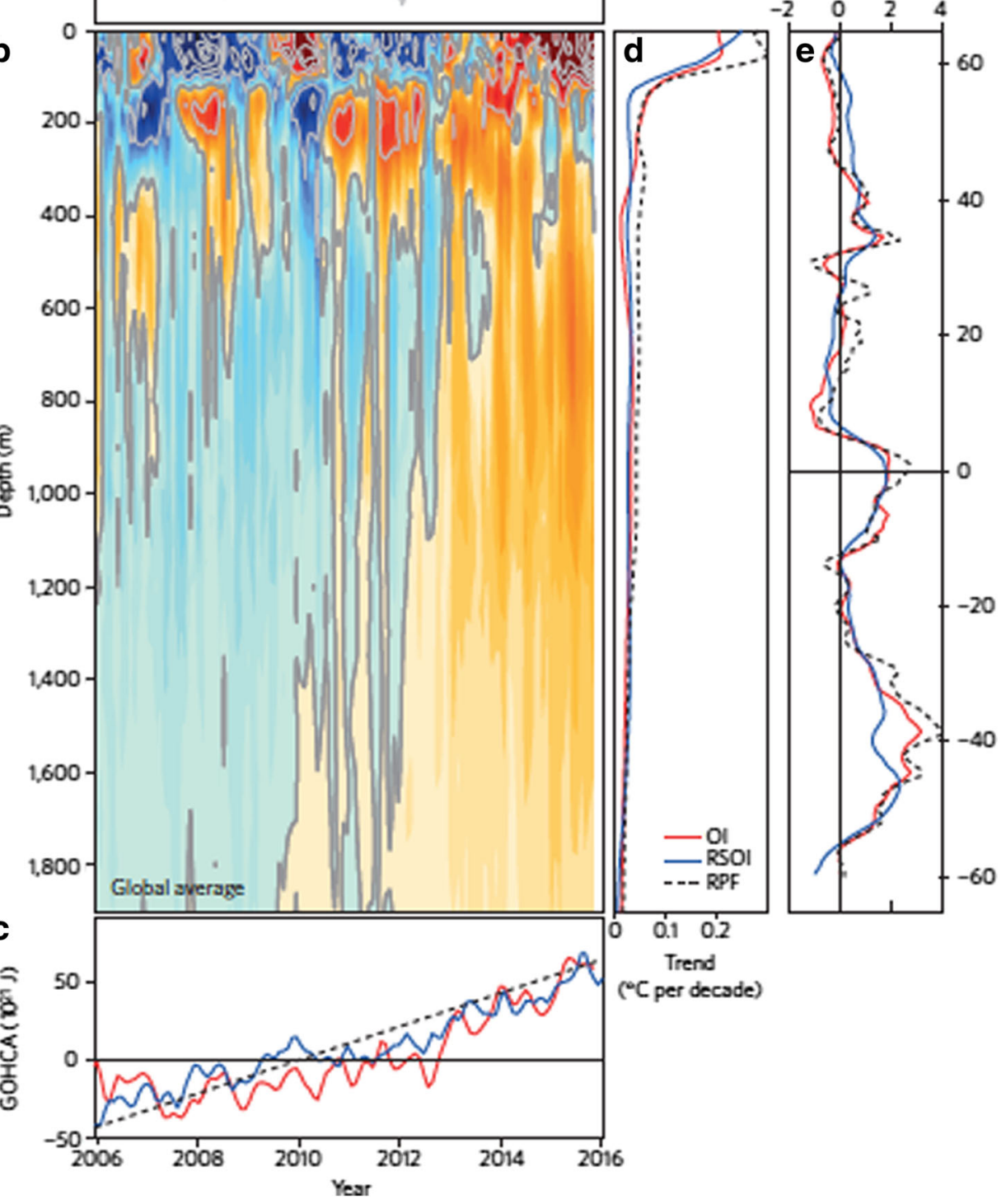

\section{OHCA in $1^{\circ}$ bands (1007 1$)$}

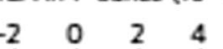

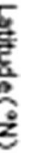

processes, meridional overturning cells (MOC) and intermediate/deep heat storage (e.g. [15, 31, 45, 56, 58, 73]). This link has received increased attention from the observational community in recent years, through the development of sustained observing systems and innovative methodologies.

\section{Observational Insights into the Regional Dynamics: an Atlantic 'Lead'}

Direct and sustained observations of the ocean circulation are difficult tasks, and there exist very few observational records capable of linking ocean dynamics and decadal variability of the climate system. Ocean reanalysis (ORA) that assimilate in situ and satellite data in a dynamical and statistical way can be used to provide such a link with satisfactory degrees of consistency (e.g. [4]). Yet, the multitude of assimilation-based analysis has to be interpreted in the light of poor observational constrains below the upper layer and large spreads between models due to the different dynamic schemes employed [52]. These sources of uncertainties and model biases are being tackled within the ocean reanalysis inter-comparison project [5], but their understanding will 
Fig. 2 The surface-to-bottom profile of global temperature trend (solid red line) computed from Argo and repeat hydrography data. The associated $95 \%$ confidence intervals are shown in dashed red lines. The bars indicate the contribution of 100-m-thick layers to the global heat uptake (relative to global surface area). Numerical values indicate the heat content trend within the upper (0-700 m), intermediate (700-2000 m), deep (2000-4000 m) and abyssal (4000-6000 m) layers. Note the different $\mathrm{x}$-axis scales used for Argo and hydrography-related profiles. The dot indicates the Argo-derived trend values and uncertainties at 2000-m depth

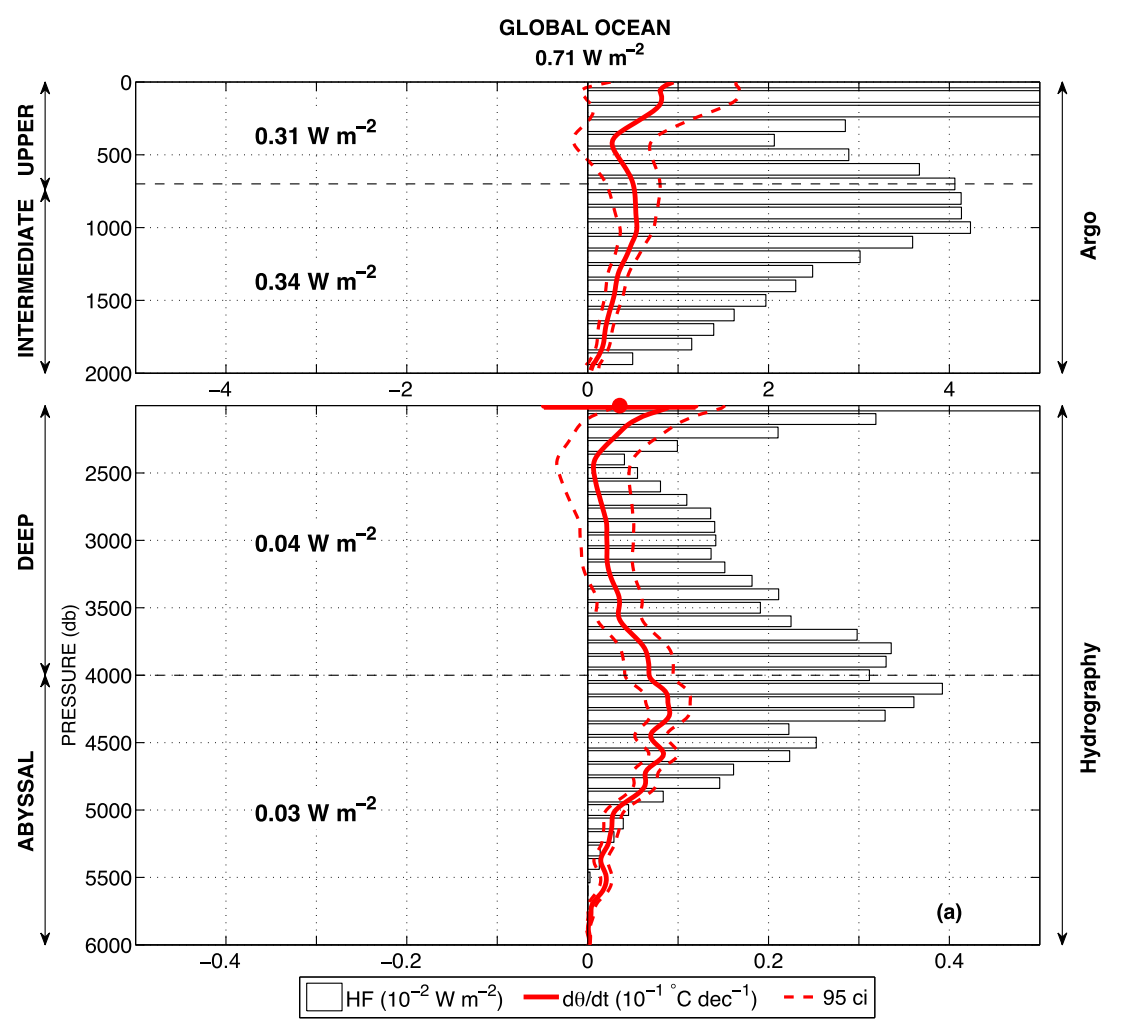

also rely on valuable observations that infer the dynamics of OHC changes.

Due to its major role in the meridional and vertical rearrangement of heat, the Atlantic became in the last decade a targeted field for innovative observational experiments. The establishment in 2004 of the RAPID-MOCHA observing system to measure the MOC at $26^{\circ} \mathrm{N}$ has led to unprecedented views on the internal dynamics of a critical ocean basin in the climate system [65]. In addition to detecting a MOC weakening over a decade of magnitude exceeding the strength predicted by climate models [63], the RAPID time-series proved the close relationship between short-term changes in oceanic heat transport $30 \%$ AMOC reduction in 2009/10) and rapid OHC events in the North Atlantic sector $\left(\sim 1.3 \times 10^{22} \mathrm{~J}\right.$ lost between $25^{\circ} \mathrm{N}$ and $\left.45^{\circ} \mathrm{N}\right)$ [7]. Promising use of altimetry data for retracing past MOC changes at $26^{\circ} \mathrm{N}$ have been proposed [18], while alternative methodologies based on coastal sea-level changes along the US east coast demonstrated the hypothesized multi-decadal correlation between circulation changes and upper $\mathrm{OHC}$ in the mid-latitude North Atlantic [44]. The dominant role of heat transport convergence in driving long-term $\mathrm{OHC}$ changes in the North Atlantic was also deduced through comprehensive analyses of ORA models [26, 73]. These multi-decadal OHC changes exert a strong influence on surface temperature patterns such as the Atlantic Multi-decadal Oscillation [11], which subsequently drive turbulent heat fluxes at the air-sea interface and associated atmospheric responses [24].
At higher latitudes, an exceptionally long hydrography time series (1975-present) of full-depth temperature and salinity in the northeastern Atlantic also showed significant interannual and decadal $\mathrm{OHC}$ fluctuations likely to be driven by circulation changes [27]. The observed upper cooling of the eastern subpolar gyre during the most recent years (2006-2014) derived from repeat hydrography appeared in line with Argo-derived trends [13], and suggested an on going eastward expansion of cold subpolar waters and a southward retreat of warm subtropical waters (e.g. $[12,25])$. A similar hydrography time series in the western subpolar gyre has recently revealed the return of intense deep convection in the winter of 2013/14, generating a new vintage of Labrador Sea Water (LSW) currently spreading within the subpolar gyre [33] and affecting the heat content of the intermediate and deep layers (e.g. [42]). The intensity of deep convection in the Greenland and Icelandic seas conversely shows a multi-decadal decline, with potential implication for the properties of the densest water masses filling the Atlantic bottom layer [48].

During the summer of 2014, the North Atlantic's observing system made another step change with the deployment of a mooring array in the Labrador Sea, Irminger Sea and Iceland basin ('Overturning in the Subpolar North Atlantic Program'-OSNAP-http://www.o-snap.org). The OSNAP array will reveal the mechanisms governing changes in the subpolar overturning circulation, and complement existing local indices based on Argo, altimetry and repeat 
hydrography (e.g. [47]). The combination of findings from RAPID and OSNAP, along with the continuing efforts to continuously monitor the meridional circulation at southern latitudes $[3,6,46]$, will soon provide new insights into ocean dynamics connectivity and the associated evolution of the Atlantic OHC.

\section{Tackling Uncertainties: a Deep Ocean Perspective}

Our understanding of $\mathrm{OHC}$ changes in the deep and abyssal ocean comes from the synoptic shipboard occupations of repeat hydrographic sections [66]. While these sections represent the most accurate component of the observing system (accuracy of $0.002{ }^{\circ} \mathrm{C}$ ), they have limited temporal resolution and spatial coverage. Following the first mapping of water masses over the globe by the World Ocean Climate Experiment (WOCE) [21], the follow-up surveys coordinated by the "Climate Variability (CLIVAR)" and the "Global Ocean Ship-based Hydrographic Investigations (GO-SHIP)" programs have yielded quantifications of the global and regional deep and abyssal changes in OHC. Purkey and Johnson [54] estimated a $0.07 \pm 0.06 \mathrm{~W} \mathrm{~m}^{-2}$ heat flux across the $2000 \mathrm{~m}$ isobar during 1993-2006 from hydrography sections occupied in 1990s and 2000s. The abyssal warming below the $4000 \mathrm{~m}$ isobar was estimated as $0.027 \pm 0.009 \mathrm{~W} \mathrm{~m}^{-2}$, with the strongest trends observed in the Southern Ocean and in deep western boundary currents along the northward routes of Antarctic Bottom Water (AABW) [34, 62]. Both slow advective processes and comparatively fast wave-like dynamics can lead to deep and abyssal $\mathrm{OHC}$ trends (e.g. [41]). Multiple factors have accordingly been proposed to explain the decadal warming of AABW, including freshening of the Ross Sea Shelf Water and the associated downward heave of isopycnal surfaces, as well as wind-driven variability of the Weddell gyre $[32,53,55]$. Updating the hydrography dataset with section repeats up to 2015 has enabled a calculation and comparison of deep and abyssal warming rates during the 1990s and 2000s decades. The comparison of these decadal changes revealed no statistically significant difference in the magnitude and structure of the global decadal warming rate at deep and abyssal levels [14]. However, there are differences in the regional trends, specifically trend reversals in the deep Atlantic and deep Pacific consistent with the simulated redistribution of heat during hiatus periods [45]. Estimations of deep temperature trends from repeat hydrography during 2003-2012 have been further combined with the Argo-based analysis of the 0-2000 m layer to yield a blended estimate of the full-depth ocean heat uptake $\left(0.71 \pm 0.12 \mathrm{~W} \mathrm{~m}^{-2}, 10 \%\right.$ found below $\left.2000 \mathrm{~m}\right)$ and a new representation of its vertical structure from the last decade of sustained observations (Fig. 2).
The reported uncertainties of hydrography-derived temperature trends below $2000 \mathrm{~m}$ remain large. There are still significant gaps in the sampling coverage that introduce an unknown bias in the above estimates (see for instance the mismatch between the Argo-derived trend and the hydrography-derived trend at $2000 \mathrm{~m}$ in Fig. 2), and alternative methodologies based on sea-level and Argo measurements raised further concerns about the significance of the reported trend in deep ocean and its contribution to the global planetary energy budget [37]. An emerging technology that will bring us closer to the closure of the global heat budget is Deep-Argo: a new observing system of profiling floats that will operate deeper than $2000 \mathrm{~m}$ [29]. The array design has been informed by analysis of core-Argo and repeat hydrographic sections [30]. Specifically, estimations of temporal and spatial decorrelation scales using full-depth CTD profiles and Argo-derived time series showed that an array deployed at 5 latitude $\times 5$ longitude $\times 15$-day cycle (about 1200 floats) would provide decadal trends of local temperature and global $\mathrm{OHC}$ below $2000 \mathrm{~m}$ with unprecedented accuracy ( 1 to $26 \mathrm{~m}^{\circ} \mathrm{C}$ decade $^{-1}$ and $3 \mathrm{TW}$, respectively). The program is at an early stage, priority is now to monitor the mechanical behaviour of deployed floats and to assess sensor behaviours and drift to validate the first temperature and salinity profiles.

\section{Conclusion}

The precise quantification and understanding of global and regional climate change is strongly dependent on how well the oceans are observed. The systematic sampling of the upper water column by Argo profiling floats marked a transition for the historical oceanographic record, until then hampered by under-sampled areas and instrumental biases that made any quantification of global $\mathrm{OHC}$ changes challenging. The Argo array has now captured a decade of temperature changes, including the warming trend driven by anthropogenic forcing. This upward ocean temperature trend is being constantly deformed by internal and external fluctuations of the climate system acting over a wide range of spatial and temporal scales. The most recent variability in global and regional $\mathrm{OHC}$ within the upper water column has been particularly assessed in the context of a significant slow-down of surface temperature rise, and focuses were consequently made on vertical rearrangements of the oceanic heat field. These global rearrangements, which appear to be dominated by variability in the top $500 \mathrm{~m}$ of the Pacific related to El-Nino type regime shifts, have been primarily understood from the analysis of numerical model output. However, innovative observational experiments have effectively elucidated some essential mechanisms of regional $\mathrm{OHC}$ variability. Amongst the major 
ocean basins, the extensive observation of the North Atlantic by a sustained moored array in the subtropics and hydrography records of unprecedented length at higher latitudes was used to decipher some links between ocean dynamics (MOC and horizontal gyres) and interannual to decadal $\mathrm{OHC}$ signals.

The repeat of hydrographic sections has demonstrated the likelihood of a concomitant warming of the water column below $2000 \mathrm{~m}$, representing about $10-15 \%$ of the whole oceanic heat uptake, and showing no sign of significant intensification during the hiatus era. The uncertain nature of this deep warming trend has highlighted the need for a sustained and systematic deep observing system that will complement the crucial repeat of shipboard measurements. The community response is the nascent Deep-Argo array, which promises to yield, in about a couple of decades, unprecedented insights into the dynamics of the abyssal circulation while providing measurements of the "missing heat" for closing the Earth energy and sea level budgets.

Acknowledgments This work is a contribution to the DEEP-C project, funded by the British National Environmental Research Council (NERC - grant NE/K004387/1). GO-SHIP CTD data were made available by data originators either as public data on the CCHDO website (http://cchdo.ucsd.edu), where cruise participants can be identified, or directly by cruise PIs. Argo data (http://doi.org/10.17882/ 42182) were collected and made freely available by the International Argo Program and the national programs that contribute to it (http:// www.argo.ucsd.edu, http://argo.jcommops.org). The Argo Program is part of the Global Ocean Observing System. The $26.5^{\circ} \mathrm{N}$ array is a collaborative effort supported through the NERC RAPID-WATCH program, the NSF meridional overturning circulation heat-flux array project and the NOAA western boundary time series project. Data from the RAPID-WATCH and MOCHA projects are freely available online (www.rapid.ac.uk/rapidmoc; www.rsmas.miami.edu/users/ mocha). We thank the many investigators who contribute to these observing systems, and gratefully acknowledge the two anonymous reviewers for their positive feedback and their help in improving the clarity of the paper.

Conflict of Interest On behalf of all authors, the corresponding author states that there is no conflict of interest.

\section{References}

1. Abraham JP, Baringer M, Bindoff NL, Boyer T, Cheng LJ, Church JA, Conroy JL, Domingues CM, Fasullo JT, Gilson J, Goni G, Good SA, Gorman JM, Gouretski V, Ishii M, Johnson GC, Kizu S, Lyman LM, Macdonal AM, Minkowycz WJ, Moffitt SE, Palmer MD, Piola AR, Reseghetti F, Schuckmann $\mathrm{K}$, Trenberth KE, Velicogna I, Willis JK. A review of global ocean temperature observations: implications for ocean heat content estimates and climate change. Rev Geophys. 2013;51:450-83. doi:10.1002/rog.20022.
2. Allan RP, Liu C, Loeb NG, Palmer MD, Roberts M, Smith D, Vidale P-L. Changes in global net radiative imbalance 1985-2012. Geophys Res Lett. 2014;41:5588-97. doi:10.1002/2014GL060962.

3. Ansorge IJ, Baringer MO, Campos EJD, Dong S, Fine RA, Garzoli SL, Meinen CS, Perez RC, Piola AR, Roberts MJ, Speich S, Sprintall J, Terre T, de Berg MAV. Basin-wide oceanography array bridges the South Atlantic. EOS. 2014;95:5354. doi:10.1002/2014EO060001.

4. Balmaseda MA, Trenberth KE, Källén E. Distinctive climate signals in reanalysis of global ocean heat content. Geophys Res Lett. 2013;40(9):1754-9. doi:10.1002/grl.50382.

5. Balmaseda MA, Hernandez F, Storto A, Palmer MD, et al. The ocean reanalyses intercomparison project (ORA-IP). J Oper Oceanogr. 2015. doi:10.1080/1755876X.2015.1022329.

6. Biastoch A, Durgadoo JV, Morrison AK, van Sebille E, Weijers W, Griffes SM. Atlantic multi-decadal oscillation covaries with Agulhas leakage. Nat Commun. 2015. doi:10.1038/ncomms10082.

7. Bryden HL, King BA, McCarthy GD, McDonagh EL. Impact of a 30 during 2009-10. Ocean Sci. 2014.

8. Chen X, Tung K-K. Varying planetary heat sink led to gobalwarming slowdown and acceleration. Science. 2014;345(6199). doi:10.1126/science.1254937.

9. Cheng Y-SL, Zhu J. Influences of the choice of climatology on ocean heat content estimation. J Atmos Ocean Technol. 2015. doi:10.1175/JTECH-D-14-00169.1.

10. Church JA, White NJ, Konikow LF, Domingues CM, Cogley JG, Rignot E, Gregory JM, van den Broeke MR, Monaghan AJ, Velicogna I. Revisiting the Earth's sea-level and energy budgets from 1961 to 2008. Geophys Res Lett. 2011; 38(L18601).

11. Delworth TL, Mann ME. Observed and simulated multidecadal variability in the Northern Hemisphere. Clim Dyn. 2000;16(9):661-76. doi:10.1007/s003820000075.

12. Desbruyères $\mathrm{D}$, Mercier $\mathrm{H}$, Thierry V. Simulated decadal variability of the meridional overturning circulation across the A25-Ovide section. J Geophys Res. 2013. doi:10.1029/2012JC008342.

13. Desbruyères D, McDonagh EL, King BA, Garry FK, Blaker AT, Moat BI, Mercier H. Full-depth temperature trends in the norteastern atlantic through the early 21 st century. Geophys Res Lett. 2014;41. doi: 10.1002/2014GL061844.

14. Desbruyères D, Purkey SG, McDonagh EL, King BA. Deep and abyssal ocean warming from 35 years of repeat hydrography. submitted to Geophys Res Lett ((a)).

15. Drijtfhout SS, Blaker AT, Josey SA, Nurser AJG, Sinha B, Balmaseda MA. Surface warming hiatus caused by increased heat uptake across multiple ocean basins. Geophys Res Lett. 2014. doi:10.1002/2014GL061456.

16. Durack PJ, Gleckler PJ, Landerer FW, Taylor KE. Quantifying underestimates of long-term upper-ocean warming. Nat Clim Chang. 2014;4:999-1005. doi:10.1038/nclimate2389.

17. England MH, McGregor S, Spence P, Meehl GA, Timmermann A, Cai W, Gupta AS, McPhaden MJ, Purich A, Santoso A. Recent intensification of wind-driven circulation in the Pacific and the ongoing warming hiatus. Nat Clim Chang. 2014. doi:10.1038/nclimate2106.

18. Frajka-Williams E. Estimating the Atlantic overturning at $26 \mathrm{n}$ using satellite altimetry and cable measurements. Geophys Res Lett. 2015;42(9):3458-64. doi:10.1002/2015GL063220.

19. Fyfe JC, Meehl GA, England MH, Mann ME, Santer BD, Flato GM, Hawkins E, Gillett NP, Xie S-P, Kosaka Y, Stewart NC. Making sense of the early-2000s warming slowdown. Nat Clim Chang. 2016;6. 
20. Gaillard F, Reynaud T, Thierry V, Kolodziejczyk N, von Schuckmann Ks. In situ-based reanalysis of the global ocean temperature and salinity with ISAS: variability of the heat content and steric height. J Clim. 2016. doi:10.1175/JCLI-D-15-0028.1.

21. Ganachaud A, Wunsch C. Large-scale ocean heat and freshwater transport during the world ocean circulation experiment. J Clim. 2003;16:696-705.

22. Gleckler PJ, Durack PJ, Stouffer RJ, Johnson GC, Forest CE. Industrial-era global ocean heat uptake doubles in recent decades. Nat Clim Chang. 2016. doi:10.1038/NCLIMATE2915.

23. Goes M, Baringer M, Goni G. The impact of historical biases on the XBT-derived meridional overturning circulation estimates at 34 s. Geophys Res Lett. 2015. doi:10.1002/2014GL061802.

24. Gulev SK, Latif M, Keenlyside N, Park W, Koltermann KP. North Atlantic Ocean control on surface heat ux on multidecadal timescales. Nature. 2013;499:464-7. doi:10.1038/nature12268.

25. Häkkinen S, Rhines PB, Worthen DL. Northern North Atlantic sea surface height and ocean heat content variability. J Geophys Res. 2013;118:3670-78. doi:10.1002/jgrc.20268.

26. Häkkinen S, Rhines PB, Worthen DL. Heat content variability in the North Atlantic Ocean in ocean reanalyses. Geophys Res Lett. 2015;42. doi:10.1002/2015GL063299.

27. Holliday NP, Cunningham SA, Johnson C, Gary SF, Griffiths C, Read JF, Sherwin T. Multidecadal variability of potential temperature, salinity, and transport in the eastern subpolar North Atlantic. J Geophys Res. 2015;120(9):5945-67. doi:10.1002/2015JC010762.

28. Johansson DJA, O’Neill BC, Tebaldi C, Häggström O. Equilibrium climate sensitivity in light of observations over the warming hiatus. Nat Clim Chang. 2015. doi:10.1038/NCLIMATE2573.

29. Johnson GC, Lyman JM. Where's the heat? Nat Clim Chang. 2014;4.

30. Johnson GC, Lyman JM, Purkey SG. Informing deep argo array design using argo and full-depth hydrography section data. J Atmos Ocean Technol. 2015. doi:10.1175/JTECH-D-15-0139.1.

31. Katsman CA, van Oldenborgh GJ. Tracing the upper ocean's "missing heat". Geophys Res Lett. 2011;38(14). doi:10.1029/2011GL048417.

32. Katsumata K, Nakano H, Kumamoto Y. Dissolved oxygen change and freshening of Antarctic Bottom water along $62 \mathrm{~s}$ in the Australian-Antarctic Basin between 1995/1996 and 2012/2013. Deep-Sea Res II. 2014;114:27-38. doi:10.1016/j.dsr2.2014.05.016.

33. Kieke D, Yashayaev IM. Studies of Labrador Sea Water formation and variability in the subpolar North Atlantic in the light of international partnership and collaboration. Prog Oceanogr. 2015;132. doi:10.1016/j.pocean.2014.12.010.

34. Kouketsu S, Doi T, Kawano T, Masuda S, Sugiura N, Sasaki Y, Toyoda T, Igarashi H, Kawai Y, Katsumata K, Uchida H, Fukasawa M, Awaji T. Deep ocean heat content changes estimated from observation and reanalysis product and their influence on sea level change. J Geophys Res. 2011;116 (C03012).

35. Lee S-K, Park W, Baringer MO, Gordon AL, Huber B, Liu Y. Pacific origin of the abrupt increase in indian ocean heat content during the warming hiatus. Nat Geosci. 2015. doi:10.1038/NGEO2438.

36. Levitus S, Antonov JI, Boyer TP, Baranova OK, Garcia HE, Locarnini RA, Mishonov AV, Reagan JR, Seidov D, Yarosh ES, Zweng MM. World ocean heat content and thermosteric sea level change (0-2000 m), 1955-2010. Geophys Res Lett. 2012;39. doi:10.1029/2012GL051106.

37. Llovel W, Willis JK, Landerer FW, Fukumori I. Deep-ocean contribution to sea level and energy budget not detectable over the past decade. Nat Clim Chang. 2014. doi:10.1038/NCLIMATE2387.
38. Loeb NG, Lyman JM, Johnson GC, Allan RP, Doelling DR, Wong T, Soden BJ, Stephens GL. Observed changes in topof-atmosphere radiation and ocean heat content consistent with uncertainty. Nat Geosci. 2012;5:110-3.

39. Lyman JM, Johnson GC. Estimating global ocean heat content changes in the upper $1800 \mathrm{~m}$ since 1950 and the influence of the climatology choice. J Clim. 2013. doi:10.1175/JCLI-D-12-00752.1.

40. Lyman JM, Good SA, Gouretski VV, Ishii M, Johnson GC, Palmer MD, Smith DM, Willis JK. Robust warming of the global upper ocean. Nature. 2010;465. doi:10.1038/nature09043.

41. Masuda S, Awaji T, Sugiura N, Matthews JP, Toyoda T, Kawai Y, Doi T, Kouketsu S, Igarashi H, Katsumata K, Uchida H, Kawano T, Fukasawa M. Simulated rapid warming of abyssal North Pacific waters. Science. 2010;329:319-22. doi:10.1126/science.1188703.

42. Mauritzen C, Melsom A, Sutton T. Importance of densitycompensated temperature change for deep North Atlantic Ocean heat uptake. Nat Geosci. 2012;5. doi:10.1038/ngeo1639.

43. McCarthy GD, Smeed DA, Johns WE, Frajka-Williams E, Moat BI, Rayner D, Baringer MO, Meinen CS, Collins J, Bryden HL. Measuring the Atlantic meridional overturning circulation at $26^{\circ} \mathrm{n}$. Prog Oceanogr. 2015a:91-111. doi:10.1016/j.pocean.2014.10.006.

44. McCarthy GD, Haigh ID, Hirschi J, Grist JP, Smeed DA. Ocean impact on decadal Atlantic climate variability revealed by sealevel observations. Nature. 2015b;521. doi:10.1038/nature14491.

45. Meehl GA, Arblaster JM, Fasullo JT, Hu A, Trenberth KE. Model-based evidence of deep-ocean heat uptake during surface-temperature hiatus periods. Nat Clim Chang. 2011;1. doi:10.1038/NCLIMATE1229.

46. Meinen CS, Speich S, Perez RC, Dong S, Piola AR, Garzoli SL, Baringer MO, Gladyshev S, Campos E. Temporal variability of the meridional overturning circulation at $34.5 \mathrm{~S}$ : preliminary results from two boundary arrays in the South Atlantic. J Geophys Res. 2013;118:6461-78. doi:10.1002/2013JC009228.

47. Mercier H, Lherminier P, Sarafanov A, Gaillard F, Daniault N, Desbruyères D, Falina A, Ferron B, Gourcuff C, Huck T, Thierry V. Variability of the meridional overturning circulation at the greenland-portugal ovide section from 1993 to 2010. Prog Oceanogr. 2013. doi:10.1016/j.pocean.2013.11.001.

48. Moore GWK, Vage K, Pickart RS, Renfrew IA. Decreasing intensity of open-ocean convection in the Greenland and Iceland seas. Nat Clim Chang. 2015:877-82. doi:10.1038/nclimate2688.

49. Nieves V, Willis JK, Patzert WC. Recent hiatus caused by decadal shift in Indo-Pacific heating. Science. 2015;349(6247):532-5. doi:10.1126/science.aaa4521.

50. Palmer MD, McNeall DJ. Internal variability of Earth's energy budget simulated by CMIP5 climate models. Environ Res Lett. 2014;9. doi:10.1088/1748-9326/9/3/034016.

51. Palmer MD, McNeall DJ, Dunstone NJ. Importance of the deep ocean for estimating decadal changes in 'Earth's radiation balance. Geophys Res Lett. 2011;38.

52. Palmer MD, Roberts CD, Balmaseda M, Chang Y-S, Chepurin G, Ferry N, Fujii Y, Good SA, Guinehut S, Haines K, Hernandez F, Köhl A, Lee T, Martin MJ, Masina S, Masuda S, Peterson KA, Storto A, Toyoda T, Valdivieso M, Vernieres G, Wang O, Xue Y. Ocean heat content variability and changes in an esemble of ocean reanalyses. Clim Dyn. 2015. doi:10.1007/s00382-015-2801-0.

53. Purkey SG, Johnson GC. Antarctic Bottom Water warming and freshening: contributions to sea level rise, ocean freshwater budgets, and global heat gain. J Clim. 2013;26. doi:10.1175/JCLI-D-12-00834.1.

54. Purkey SG, Johnson GC. Warming of global abyssal and deep southern ocean waters between the 1990s and 2000s: contribution 
to global heat and sea level rise budgets. J Clim. 2010;23:633650. doi:10.1175/2010JCLI3682.1.

55. Purkey SG, Jonhson GC. Global contraction of Antarctic Bottom Water between the 1980s and 2000s. J Clim. 2012;25: 5830-44.

56. Rahmstorf S, Box JE, Feulner G, Mann ME, Robinson A, Rutherford S, Schaffernicht EJ. Exceptional twentieth-century slowdown in Atlantic Ocean overturning circulation. Nat Clim Chang. 2015;5:475-80. doi:10.1038/nclimate2554.

57. Rhein M, Rintoul SR, Aoki S, Campos E, Chambers D, et al. Observations: oceans, in climate change 2013: the physical basis. In: Stocker T, Qin D, Plattner G-K, Tignor M, Allen SK, et al., editors. Contribution of working group I to the fifth assessment report of the intergovernmental panel on climate change. Cambridge: Cambridge University Press; 2013. p. 255-310.

58. Robson J. Atlantic overturning in decline? Nat Geosci. 2014

59. Roemmich D, Gilson J. The 2004-2008 mean and annual cycle of temperature, salinity, and steric height in the global ocean from the Argo Program. Prog Oceanogr. 2009;82:81-100. doi:10.1016/j.pocean.2009.03.004.

60. Roemmich D, Church J, Gilson J, Monselesan D, Sutton $\mathrm{P}$, Wijffels $\mathrm{S}$. Unabated planetary warming and its ocean structure since 2006. Nat Clim Chang. 2015. doi:10.1038/NCLIMATE2513.

61. Shindell DT. Inhomogeneous forcing and transcient climate sensitivity. Nat Clim Chang. 2014:274-7.

62. Sloyan B, Wijffels SE, Tilbrook B, Katsumata K, Murata A, Macdonal AM. Deep ocean changes near the western boundary of the South Pacific Ocean. J Phys Oceanogr. 2013:2132-41. doi:10.1175/JPO-D-12-0182.1.

63. Smeed DA, McCarthy GD, Cunningham SA, Frajka-Williams E, Rayner D, Johns WE, Meinen CS, Baringer MO, Moat BI, Duchez A, Bryden HL. Observed decline of the Atlantic merid- ional overturning circulation 2004-2012. Ocean Sci. 2014;10:29_ 38.

64. Smith DM, Allan RP, Coward AC, Eade R, Hyder P, Liu C, Loeb NG, Palmer MD, Roberts CD, Scaife AA. Earth's energy imbalance since 1960 in observations and cmip5 models. Geophys Res Lett. 2015. doi:10.1002/2014GL062669.

65. Srokosz MA, Bryden HL. Observing the atlantic meridional overturning circulation yields a decade of inevitable surprises. Science. 2015;348. doi:10.1126/science. 1255575.

66. Talley LD, Feely RA, Sloyan BM, et al. Changes in ocean heat, carbon content, and ventilation: a review of the first decade of GO-SHIP global repeat hdrography. Ann Rev Mar Sci. 2016:185215.

67. Tollefson J. 2015 breaks heat record. Nature. 2016;529.

68. Trenberth KE, Fasullo JT. Tracking earth's energy. Science. 2010;328:316-7.

69. Trenberth KE, Fasullo JT. An apparent hiatus in global warming? Earth's Future. 2013;1(1):19-32. doi:10.1002/2013EF000165.

70. Trenberth KE, Fasullo JT, Balmaseda MA. Earth's energy imbalance. J Clim. 2014:3129-44.

71. von Schuckmann K, Palmer MD, Trenberth KE, Cazenave A, Chambers D, Champollion N, Hansen J, Josey SA, Loeb N, Mathieu P-P, Meyssignac B, Wild M. An imperative to monitor earth's energy imbalance. Nat Clim Chang. 2016. doi:10.1038/NCLIMATE2876.

72. Wijffels S, Roemmich D, Monselesan D, Church J, Gilson J. Ocean temperatures chronicle the ongoing warming of earth. Nat Clim Chang. 2016:116-8. doi:10.1038/nclimate2924.

73. Williams RG, Roussenov V, Smith D, Lozier MS. Decadal evolution of ocean thermal anomalies in the North Atlantic: the effects of Ekman, overturning, and horizontal transport. J Clim. 2014.

74. Xie S-P. Oceanogrpahy: leading the hiatus research surge. Nat Clim Chang. 2016;6:345-6. doi:10.1038/nclimate2973. 